\title{
ESTIMATION OF SUBSURFACE STRUCTURE BASED ON MICROTREMOR, BORE HOLE OBSERVATIONS AND STOCHASTIC STRONG GROUND MOTION SIMULATIONS IN PALU CITY, CENTRAL SULAWESI, INDONESIA: A VALIDATION AND SENSITIVITY STUDY ON THE 23 JANUARY 2005 (PALU) EARTHQUAKE
}

\author{
Pyi Soe Thein $^{* 1}$, Subagyo Pramumijoyo ${ }^{2}$, Wahyu Wilopo ${ }^{2}$, Agung Setianto ${ }^{2}$, Kirbani Sri \\ Brotopuspito $^{3}$, and Junji Kiyono ${ }^{4}$ \\ ${ }^{1}$ Geology Department, Yadanabon University, Mandalay, Myanmar \\ ${ }^{2}$ Geological Engineering Department, Favulty of Engineering, Gadjah Mada University, Yogyakarta, Indonesia \\ ${ }^{3}$ Physics Department, Gadjah Mada University, Yogyakarta, Indonesia \\ ${ }^{4}$ Graduate School of Global Environmental Studies, Kyoto University, Kyoto, Japan
}

\begin{abstract}
In this study, we investigated the subsurface structure and strong ground motion parameters for Palu City. One of the major structures in Central Sulawesi is the Palu-Koro Fault system. Several powerful earthquakes have struck along the Palu-Koro Fault during recent years, one of the largest of which was an M 6.3 event that occurred on January 23, 2005 and caused several casualties. Following the event, we conducted a microtremor survey to estimate the shaking intensity distribution during the earthquake. From this survey we produced a map of the peak ground acceleration, velocity and ground shear strain in Palu City. We performed single observations of microtremors at 151 sites in Palu City. The results enabled us to estimate the site-dependent shaking characteristics of earthquake ground motion. We also conducted 8-site microtremor array investigation to gain a representative determination of the soil condition of subsurface structures in Palu.
\end{abstract}

${ }^{*}$ Corresponding author: P.S. THEIN, Geology Department, Yadanabon University, Mandalay, Myanmar. Email: pyisoethein@yahoo.com
From the dispersion curve of array observations, the central business district of Palu corresponds to relatively soil condition with $V s \leq 300 \mathrm{~m} / \mathrm{s}$, the predominant periods due to horizontal vertical ratios (HVSRs) are in the range of 0.4 to $1.8 \mathrm{~s}$ and the resonant frequency are in the range of 0.7 to $3.3 \mathrm{~Hz}$. Three boreholes were throughout the basin especially in Palu area to evaluate the geotechnical properties of subsurface soil layers. The depths are varying from $1 \mathrm{~m}$ to $30 \mathrm{~m}$. Strong ground motions of the Palu area were predicted based on the empirical stochastic green's function method. Peak ground acceleration and peak ground velocity becomes more than $0.04 \mathrm{~g}$ and 30 kine in some areas, which causes severe damage for buildings in high probability.

Keywords: Palu-Koro fault, microtremor, bore holes, peak ground acceleration and velocity.

\section{Introduction}

Sulawesi Island, eastern Indonesia, is located at the junction between the converging PacificPhilippine, Indo-Australian Plates and the Sundaland, i.e., the south-eastern part of the 


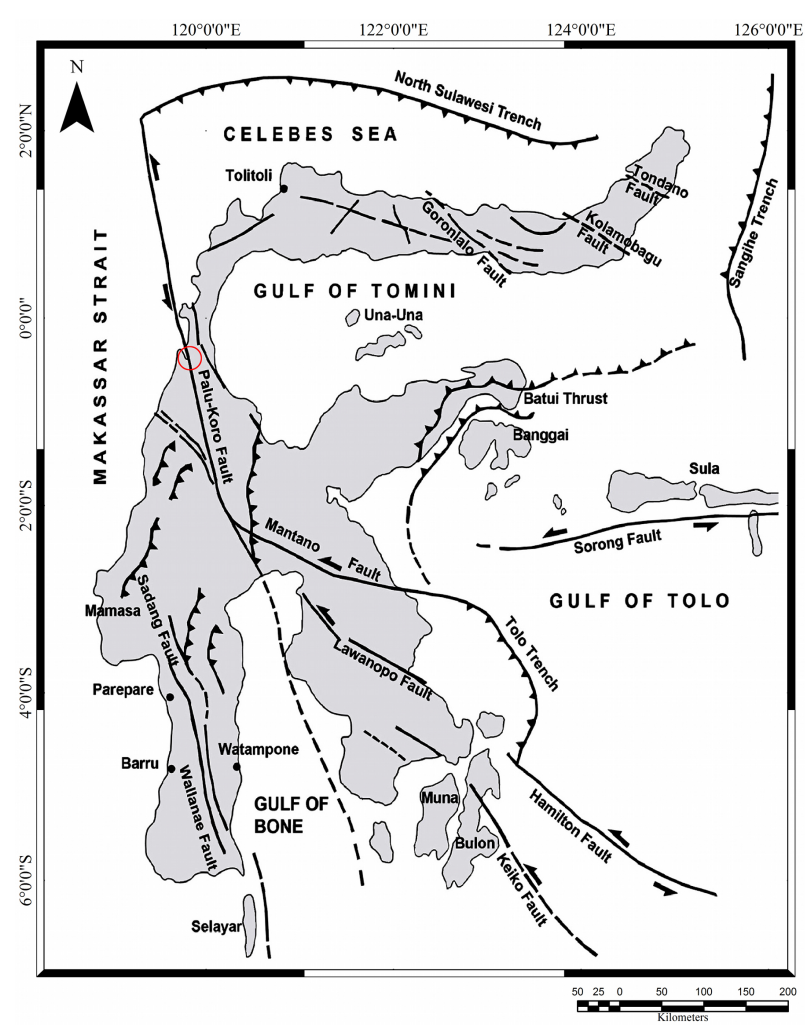

Figure 1: Tectonic map of Sulawesi, (Priadi, 1993). Red circle: Palu depression area.

Eurasian Plate. The Central Sulawesi Fault System, one of the major structures in SE Asia, cuts across Sulawesi Island from NW to SE, connecting the North Sulawesi subduction zone to the Banda Sea deformation zones. One of the major structures in Central Sulawesi is the PaluKoro Fault system, which extends NNW- SSE direction and cross cuts Sulawesi along more than $300 \mathrm{~km}$, from the North Sulawesi trench pass through Palu Bay, southward turn to the SE connect to the Matano and Lawanopo Faults and further eastward, both faults join to Tolo trench, (Priadi, 1993) (Figure 1). In this study, Palu, where a large earthquake is expected in the near future, is considered to be a target area (Thein et al., 2013).

We carried out higher density single point observations and larger radius array observations. Based on the observed data, we calculated the distribution of the predominant, depth of the engineering bed rock and phase velocities of the Rayleigh wave in Palu City.

\section{Seismicity}

Seismicity of Palu was reported since $19^{\text {th }}$ century. Location of epicenters and level of intensity were still approximate based on the European resident note. Earthquake is one of the most devastating natural phenomena. The most important earthquakes that stroke Palu, are in 1927. These earthquakes caused 2,500 people died and 750 houses were severely damaged. These data show that Palu depression area is very vulnerable to earthquake disasters (USGS, 2007).

1. December 1, 1927 earthquake, this earthquake originated at $-0.7^{\circ} \mathrm{S}$ and $119.7^{\circ} \mathrm{E}$ with the magnitude of 6.3. It shocked West Central Sulawesi, Palu City area, resulted in $15 \mathrm{~m}$ height tsunami occurred, 14 killed, 30 injured and 0.5 to $12 \mathrm{~m}$ subsidence.

2. March 7, 1960 earthquake, it occurred at $1.5^{\circ} \mathrm{N}$ and $125.5^{\circ} \mathrm{E}$ with moderate intensities in regional scale with the magnitude of 5.1 and the depth of $60 \mathrm{~km}$.

3. April 11, 1967 earthquake, this earthquake occurred at $-3.3^{\circ} \mathrm{S}$ and $119.4^{\circ} \mathrm{E}$ with the magnitude of 6.3 and thrust fault mechanism. Tinambung area felt maximum intensity of VIII -VIII, resulted in 58 killed, 100 injured and the water suddenly retreated.

4. August 14, 1968 earthquake, it originated at $-0.7^{\circ} \mathrm{N}$ and $118.8^{\circ} \mathrm{E}$ with high intensities magnitude of 7.4 and normal fault mechanism. West Central Sulawesi, Palu bay felt maximum intensity of VIII -VIII, resulted in $10 \mathrm{~m}$ height tsunami occurred, 200 died, 2-3 m subsidence in Mapaga village and 2$3 \mathrm{~m}$ subsidence.

5. February 2, 1969 earthquake, this earthquake happened at the epicenter of $-3.1^{\circ}$ $\mathrm{S}$ and $118.5^{\circ} \mathrm{E}$ with the magnitude of 6 . South Sulawesi, Majene area felt maximum intensities of VIII with thrust fault mechanism, resulted in 2 to $6 \mathrm{~m}$ height tsunami occurred, 64 killed and over 1,200 buildings were wrecked. Eighty percent of the brick structures were damaged, and some completely collapsed. Ground fissures were noted in several places. Several 
wooden houses located at the end of a bay were swept away by the waves. The press reported that the tsunami took 600 lives.

6. March 3, 1977 earthquake, this earthquake occurred at $-1.99^{\circ} \mathrm{N}$ and $123.05^{\circ} \mathrm{E}$ with the magnitude of 5.4 and the depth of $58 \mathrm{~km}$.

7. January 8, 1984 earthquake, this earthquake occurred at $-2.77^{\circ} \mathrm{S}$ and $118.8^{\circ} \mathrm{E}$ with the magnitude of 6.6. The maximum intensity of the earthquake was VII in Mamuju area with thrust fault mechanism.

8. January 1, 1996 earthquake, this earthquake happened at $-0.83^{\circ} \mathrm{N}$ and $120.1^{\circ} \mathrm{E}$ with moderate and high intensities in regional scale with the magnitude of 7.7. It shocked West coast Central Sulawesi area, resulted in 1.0 to 3.4 tsunami height occurred, 0.5 to $2.0 \mathrm{~m}$ subsidence, 9 killed and 63 injured.

9. January 23, 2005 earthquake, this earthquake occurred at $-1.198^{\circ} \mathrm{S}$ and $119.933^{\circ} \mathrm{E}$ with the magnitude of 6.3 and the depth of $20 \mathrm{~km}$ in Sulawesi.

10. August 30, 2011 earthquake, this earthquake occurred at $6.401^{\circ} \mathrm{S}$ and $126.774^{\circ} \mathrm{E}$ with the magnitude of 6.8 and the depth of $465 \mathrm{~km}$.

11. August 18, 2012 earthquake, this earthquake happened at $-1.21^{\circ} \mathrm{S}$ and $120.08^{\circ} \mathrm{E}$ with the magnitude of 6.2 and the depth of $40 \mathrm{~km}$. In Kulawi, Palu City, resulted in heavy damaged buildings.

\section{Geology}

Evolution of Neogene kinematics along the Palu-Koro fault was confirmed based on microtectonics approach, i.e., sinistral strike-slip due to E-W compression, radial extensions caused by telescoping vertical movement of Neogene granitoid, and then left lateral with normal component displacement due to N-S extension/ E-W compression which is still active actually (Pramumijoyo et al., 1997). Palu depression area is filled by mostly clay, silt, and sand deposits as alluvial deposits, except on the border east or west consist of gravelly sands as colluvial wedges. The composition of gravel is granitic fragment to the northwest, mostly of

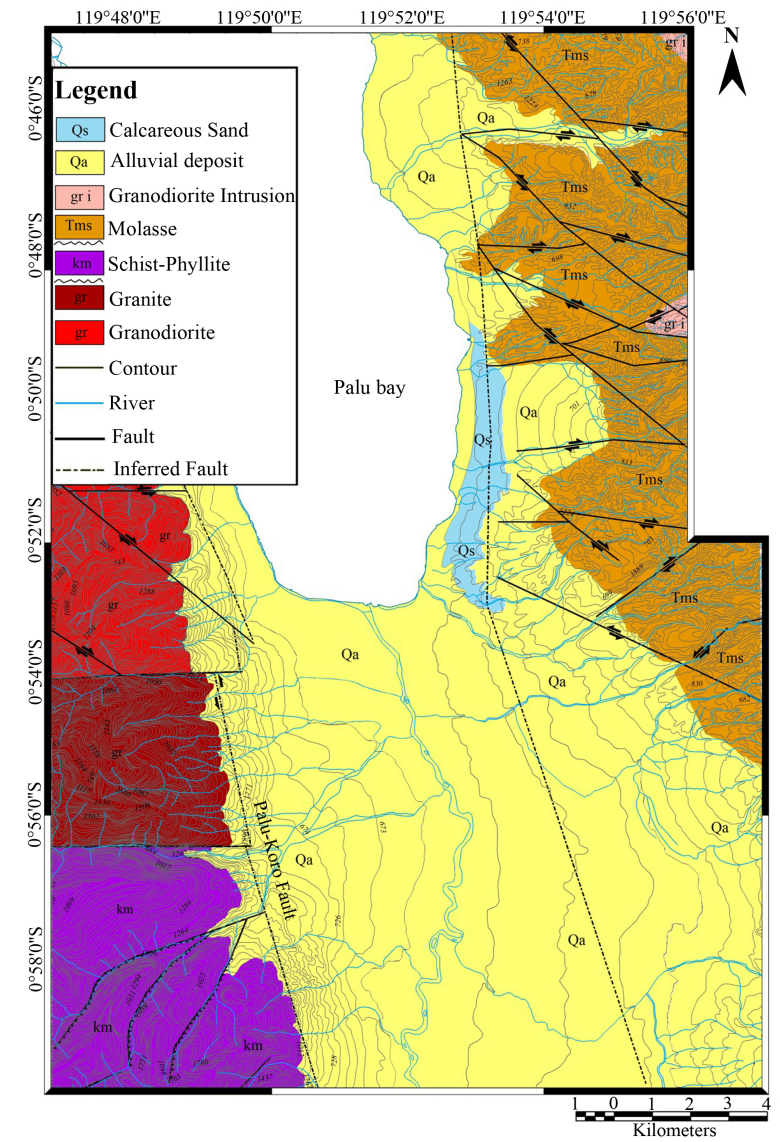

Figure 2: Geological map of Palu depression area (Ananda, 2013; Indra, 2013; Ismawan, 2013; and Juwanto, 2013).

schist on the west and to the east the gravel consists of schist, igneous and sedimentary rocks. West escarpment to the north consists of granite and granodiorite units, and to the south consists of schist-phyllitic units. East escarpment consists of molasses (Soekamto, 1995). Figure 2 shows geological map of Palu depression area.

\section{The GIS based model proposed for seismic microzonation}

The GIS based model that can be used to create the infrastructure of seismic microzonation studies on Palu City that have a risk in terms of natural disaster, particularly earthquake. In addition, a relational database was designed to cope with the damage resulting from natural hazards for this study.This model was applied so as to take the measures needed for the City of Palu located on the segments of the Palu-Koro 
Fault Zone, a settlement with earthquake risk on the natural disaster. During creation of the system, geological, geotechnical data and data produced from aerial photos were integrated and assessed on a GIS environment. The infrastructure for seismic microzonation was created using this model. The potential areas for strong ground motion were detected in the study area. Thus, the future results were produced to assist in seismic microzonation.

\section{Microtremor single station observa- tions}

A three-component accelerometer with data logger, GPL-6A3P, produced by the Mitsutoyo Co. Ltd., was used. The number of single point observations was 151 (Figure 3 a). The sampling frequencies were $100 \mathrm{~Hz}$ or $500 \mathrm{~Hz}$ and the observation times were 10 to $15 \mathrm{~min}$ utes. This exploration method was established after the pioneering work done by Aki (1957). Although there are 151 observation points, the points are not adequate to cover all the target area. If each value of the predominant period obtained is considered to be a realization of a stochastic random field. Space interpolation is conducted by ordinary kriging technique (Kiyono et al., 1996). The results are shown in Figure 3p. The predominant periods of 1.0-1.8 seconds were on the alluvial fan area. The spatial correlations between predominant periods on the west side mountain, of which slope is steep, are shorter than those in the east side mountain and change more rapidly.

\section{Microtremor array observations}

We carried out array observations at eight sites in Palu (Figure 3k). Four accelerometers were used in each array observation site. One was installed at a center of the circle with a radius (r). Other three were arranged on the circle with a shape of regular triangle. Observation duration time was 20 30 minutes and sampling frequency was $100 \mathrm{~Hz}$. Sequential observations were conducted three times by changing the array radius; $r=3,10$ and 30 meters. Dispersion curves were calculated using the SPAC method. The velocity of surface wave is well known to vary as a function of frequency (or period) due to dispersive characteristics. Therefore, the subsurface structure can be estimated from observed dispersion curve. Then, a substructure profile was identified from the dispersion curve by using the Particle Swarm Optimization (Keneddy, 1995; Noguchi et al., 2009).

The dispersion curves obtained are shown in Figure $4 \mathrm{a}-\mathrm{c}$ for each survey. For line A, the phase velocity corresponding to shallow ground with a high frequency range is about $369 \mathrm{~m} / \mathrm{s}$ at APP, about $423 \mathrm{~m} / \mathrm{s}$ at GWL, about $318 \mathrm{~m} / \mathrm{s}$ at KDM, about $318 \mathrm{~m} / \mathrm{s}$ at KRP, about $279 \mathrm{~m} / \mathrm{s}$ at LSS, about $348 \mathrm{~m} / \mathrm{s}$ at MOP, about $285 \mathrm{~m} / \mathrm{s}$ at MSQ and about $317 \mathrm{~m} / \mathrm{s}$ at SGI. The soft ground extended beneath LSS, which is the nearest site to the coast. The ground beneath the sites higher than GWL has relatively hard surface soil compared with the plain along the coast. Since the minimum phase velocity in the high frequency range is around $300 \mathrm{~m} / \mathrm{s}$, the soil profile is very similar along line $B$ and line C. The dispersion curves obtained here had no discrepancies in the distribution of topography, altitude and predominant period. We could estimate subsurface sedimentary layers in the plains using these dispersion curves.

\section{Estimations vs structure and inversion}

\subsection{Application of PSO}

By conducting an inversion analysis using the Particle Swarm Optimization (PSO) algorithm on the above dispersion curves, the subsurface structure beneath the site can be estimated. The PSO is a solution method for a non-linear optimization problem. We estimate the subsurface structure of the model by minimizing the difference between the observed and theoretical phase velocity curves (Kiyono et al, 2011).

$$
F=\sum_{i=1}^{N} w_{i} \sqrt{\left(c_{i}^{0}\right)^{2}-\left(c_{i}^{T}\right)^{2}}
$$

where $F$ is an objective function that should be minimized, $c_{i}^{0}$ and $c_{i}^{T}$ are the observed and theoretical phase velocities, and $w_{i}$ is a weighting function. $c_{i}^{0}$ and $c_{i}^{T}$ are given in discretized 

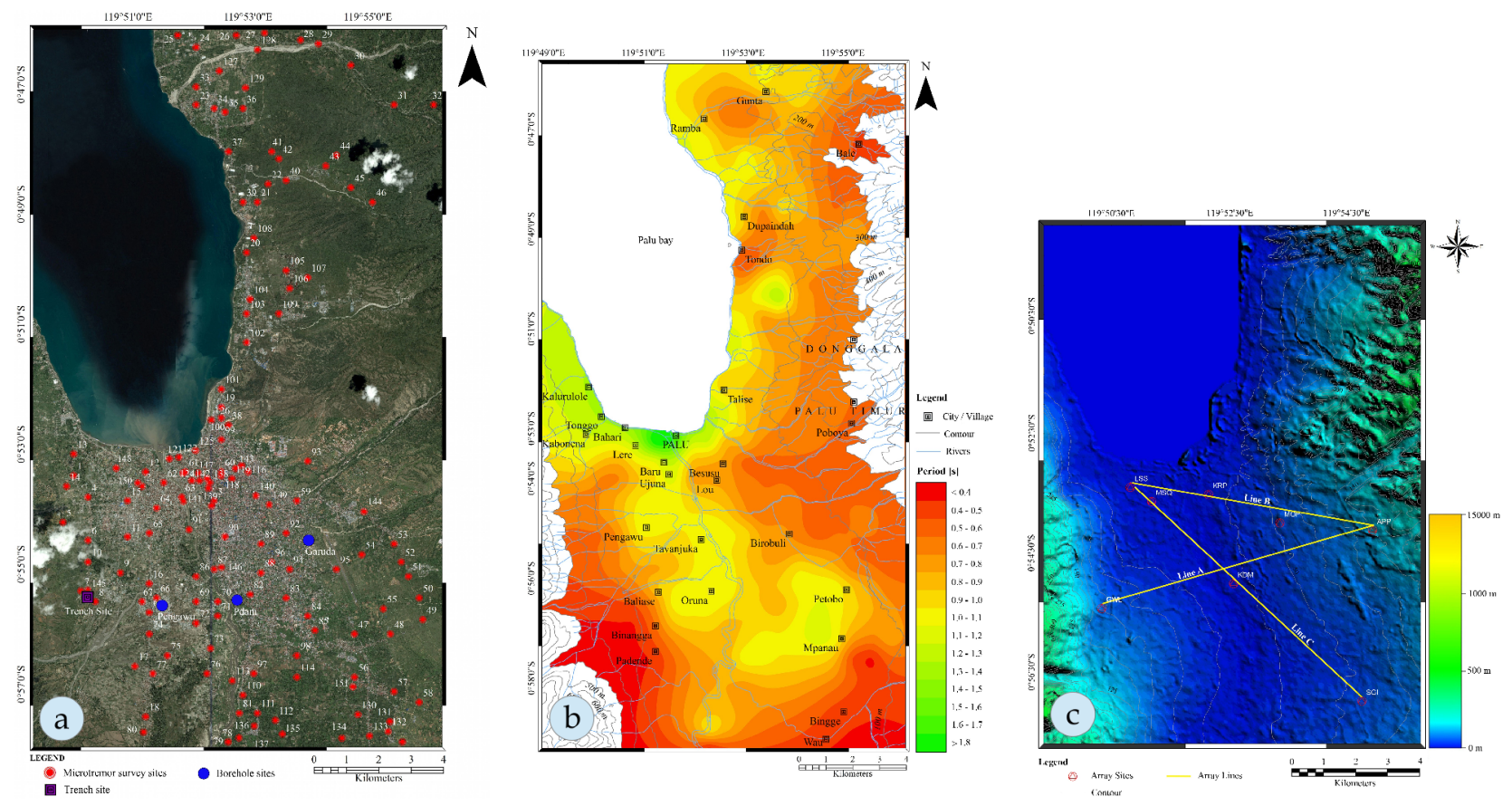

Figure 3: (a) Location of the mitcrotremor observation, boreholes sites and the situation of the trench making at Palu City; (b) Spatial distributions of longer predominant period; (c) Three survey lines for array observation (Line A, Line B, and Line C).
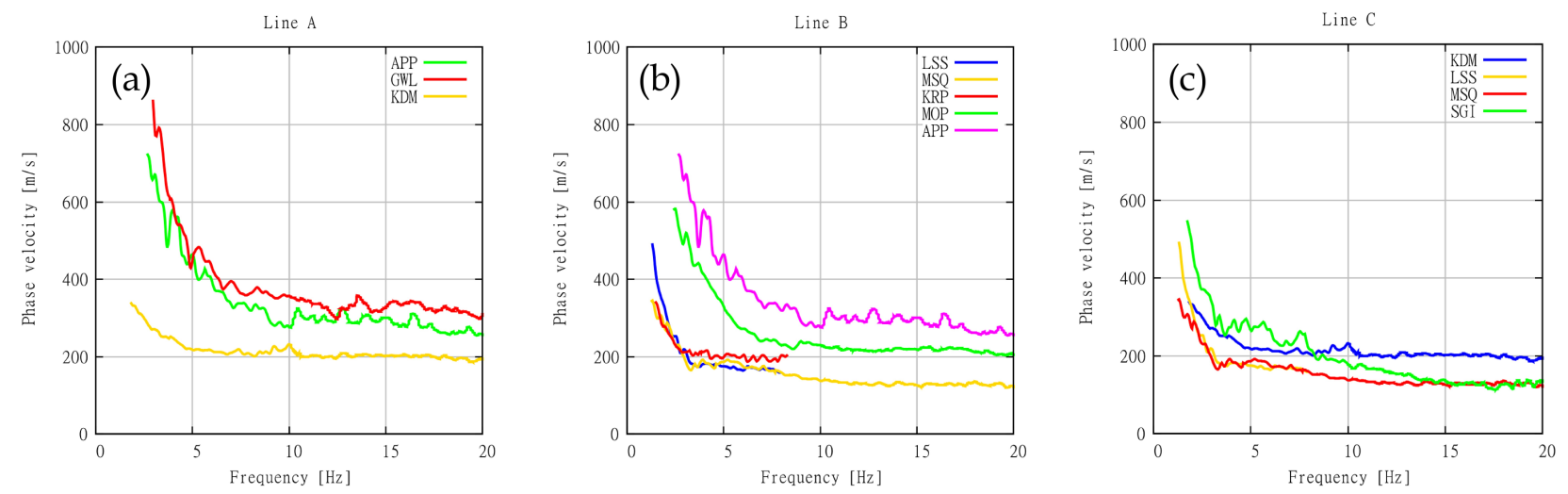

Figure 4: Dispersion curves obtained for each survey line (a) Line A, (b) Line B and (c) Line C. 
frequency $(i=1,2, \ldots, N)$. The PSO uses a particle swarm that has information about position and velocity. The particle swarm moves around the space with updating information and settles at the optimized point. During the optimization, the particle swarm has a best solution for both the group ( $g$-best) and individual ( $p$-best) in every step. The basic procedure of PSO is as follows. After setting the initial values of the number of particles and iterations, an initial position and velocity are given to $x_{d}^{k}$ and $v_{d}^{k}$, in which $d$ is a particle number. The value of the objective function is calculated for each particle. The best solutions for the particle, $d$, and for the group, $g$, at $k$-th iteration are defined as $p_{d}^{k}$ and $p_{g}^{k}$. The the position and velocity are updated as

$$
\begin{gathered}
v_{d}^{k+1}=w v_{d}^{k}+c_{1} r_{1}\left(p_{d}^{k}-x_{d}^{k}\right)+c_{2} r_{2}\left(p_{g}^{k}-x_{d}^{k}\right) \\
x_{d}^{k+1}=x_{d}^{k}+v_{d}^{k+1}
\end{gathered}
$$

where $r_{1}$ and $r_{2}$ are random values with the range of $[0,1], c_{1}$ and $c_{2}$ are constants, and $w$ is the inertia weighting. This process is repeated as $k=k+1$ until the number of iterations exceed a setting value. Before performing the inversion analysis, the subsurface structure was assumed to consist of horizontal layers of elastic and homogeneous medium a semi-infinite elastic body. The shear wave velocity and thickness of each layer are the parameters that were determined by inversion analysis. The results obtained enable us to determine the soil condition of the subsurface structure. Figure 5 shows $V_{s}$ structures of the ground along the survey lines (a) Line A, (b) Line B and (c) Line C.

\subsection{Inversion}

The identified soil parameters by the inversion at MSQ and GWL are shown in Table 1 and 2. Figure 6 show dispersion curves of the ground along the survey lines at MSQ and (b) GWL, respectively.
Table 1: Identified ground parameters at MSQ.

\begin{tabular}{|c|c|c|c|c|}
\hline Layer & $\rho\left[\mathrm{t} / \mathrm{m}^{3}\right]$ & $V_{p}[\mathrm{~m} / \mathrm{s}]$ & $V_{s}[\mathrm{~m} / \mathrm{s}]$ & $H[\mathrm{~m}]$ \\
\hline 1 & 1.7 & 798 & 124 & 22 \\
\hline 2 & 1.8 & 1303 & 319 & 66 \\
\hline 3 & 1.9 & 1496 & 413 & 198 \\
\hline
\end{tabular}

Table 2: Identified ground parameters at GWL.

\begin{tabular}{|c|c|c|c|c|}
\hline Layer & $\rho\left[\mathrm{t} / \mathrm{m}^{3}\right]$ & $V_{p}[\mathrm{~m} / \mathrm{s}]$ & $V_{s}[\mathrm{~m} / \mathrm{s}]$ & $H[\mathrm{~m}]$ \\
\hline 1 & 1.7 & 1338 & 335 & 10 \\
\hline 2 & 1.8 & 1361 & 346 & 26 \\
\hline 3 & 1.9 & 1814 & 588 & 63 \\
\hline
\end{tabular}

\section{Modeling of subsurface soil structure}

We could obtain $V_{s}$ structures at array observation sites, however, the ground profiles are not uniquely determined. In this study, we proposed simple two layer model in Palu by averaging the first three layers of all array sites. Shear wave velocity of the first layer modeled is $300 \mathrm{~m} / \mathrm{sec}$. By combining with the first peak of $H / V$ data, we can obtain the thickness of the first layer. The technique used was the $1 / 4$ wavelength principle, which can approximately be extended to multi layered media.

$$
T=4 H / V_{s}
$$

where, $H$ is a thickness of a layer, $V s$ shear wave velocity and $T$ predominant period. The distribution of thickness for the first layer of which $V_{s}$ is $\leq 300 \mathrm{~m} / \mathrm{s}$ in Palu area is shown in Figure 7, in which the rapidly varying area of the subsurface condition and dense observation area are enclosed. The shear wave velocities, $V_{s}^{*}$ of layers are calculated by the weighted average, for which the weight is the reciprocal of square of distance from the array observation points, APP, GWL, KDM, LSS, MOP, MSQ and SGI, as

$$
V_{s}^{*}=\frac{\sum \frac{V_{s_{i}}}{x_{i}^{2}}}{\sum \frac{1}{x_{i}^{2}}}
$$

where, $i$ defines the array sites $(i=1,2, \ldots$ 7 ), and $x_{i}$ indicates the distance between an array observation site and the center of the mesh. 

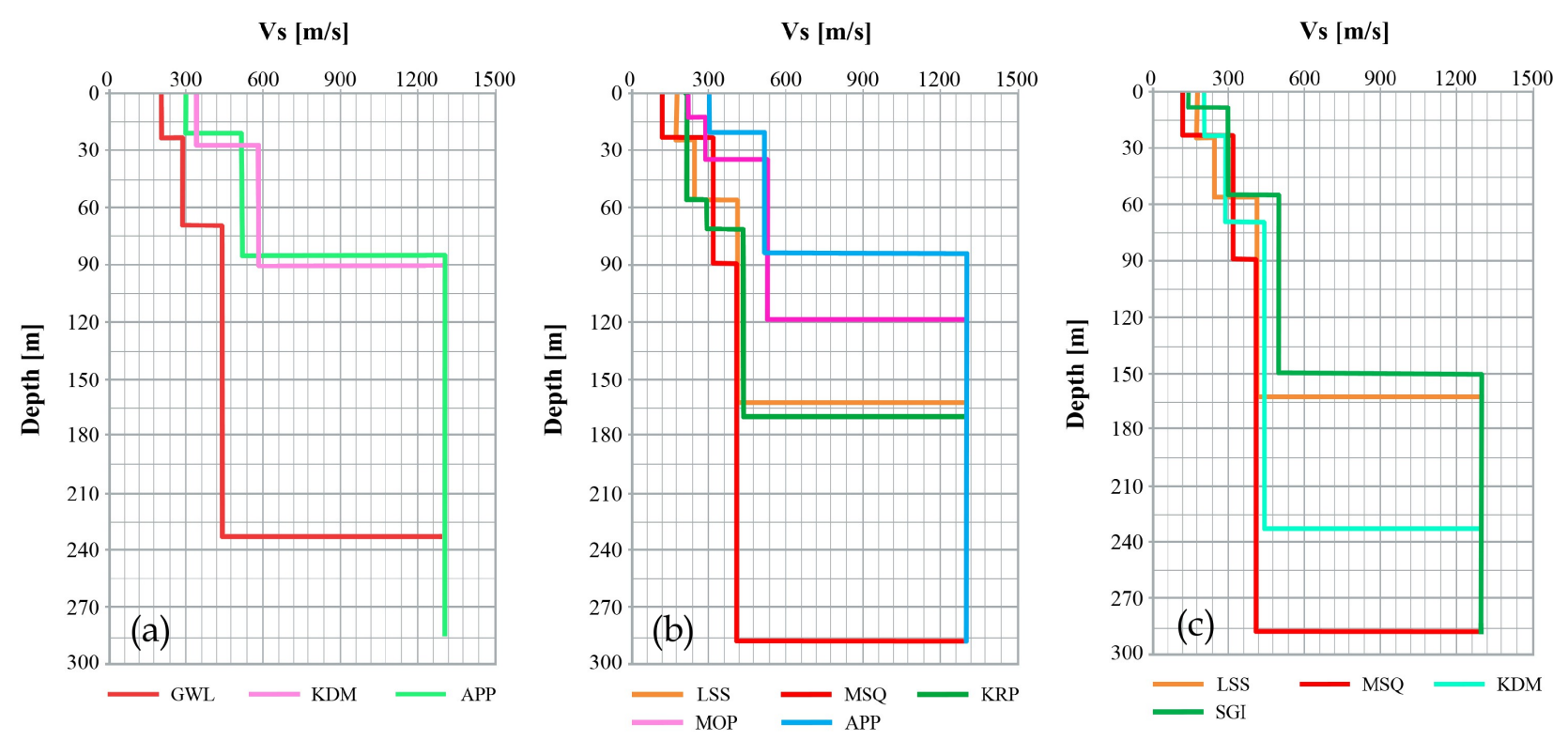

Figure 5: $V_{s}$ structures of the ground along the survey lines (a) Line A, (b) Line B and (c) Line C.
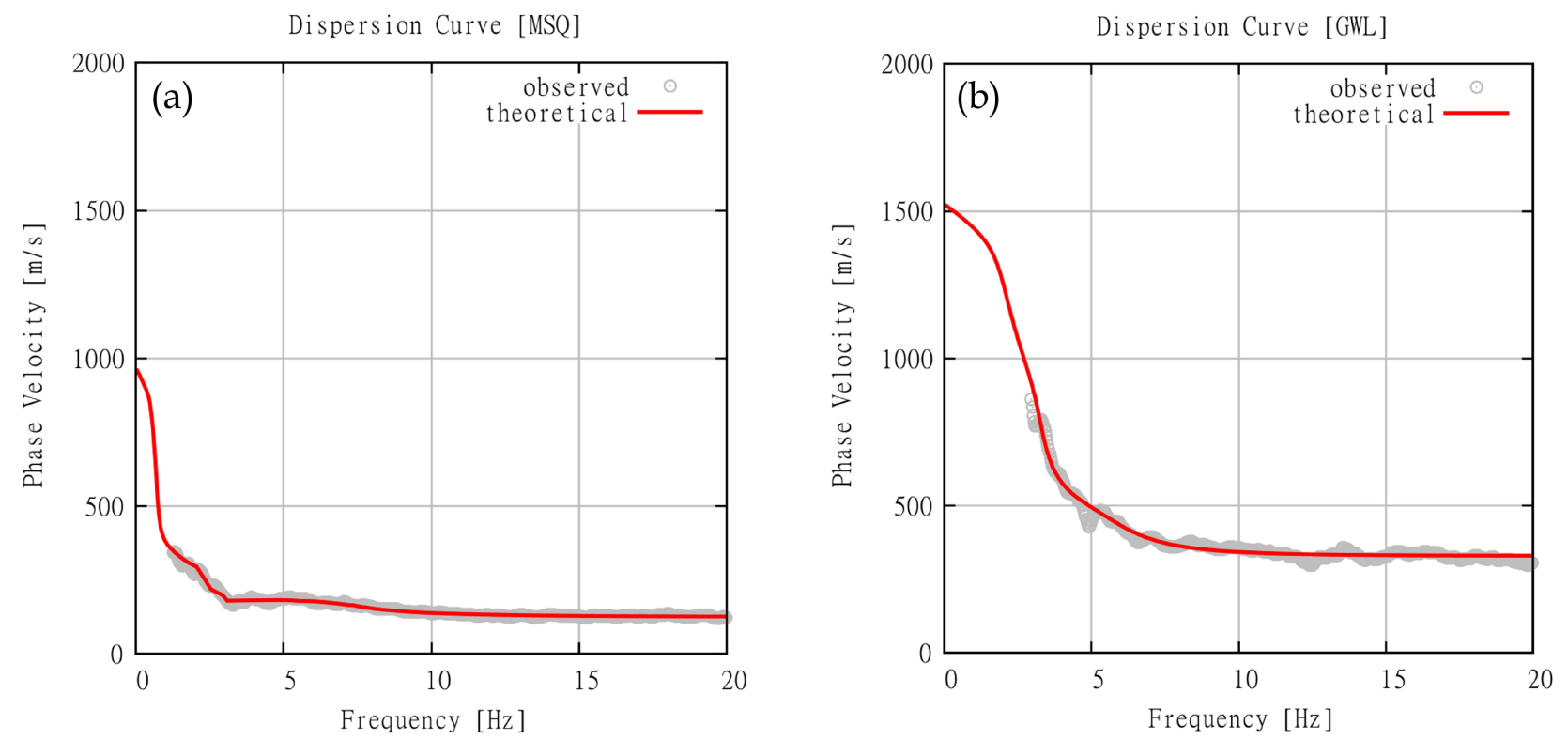

Figure 6: Dispersion curves at (a) MSQ and (b) GWL. 


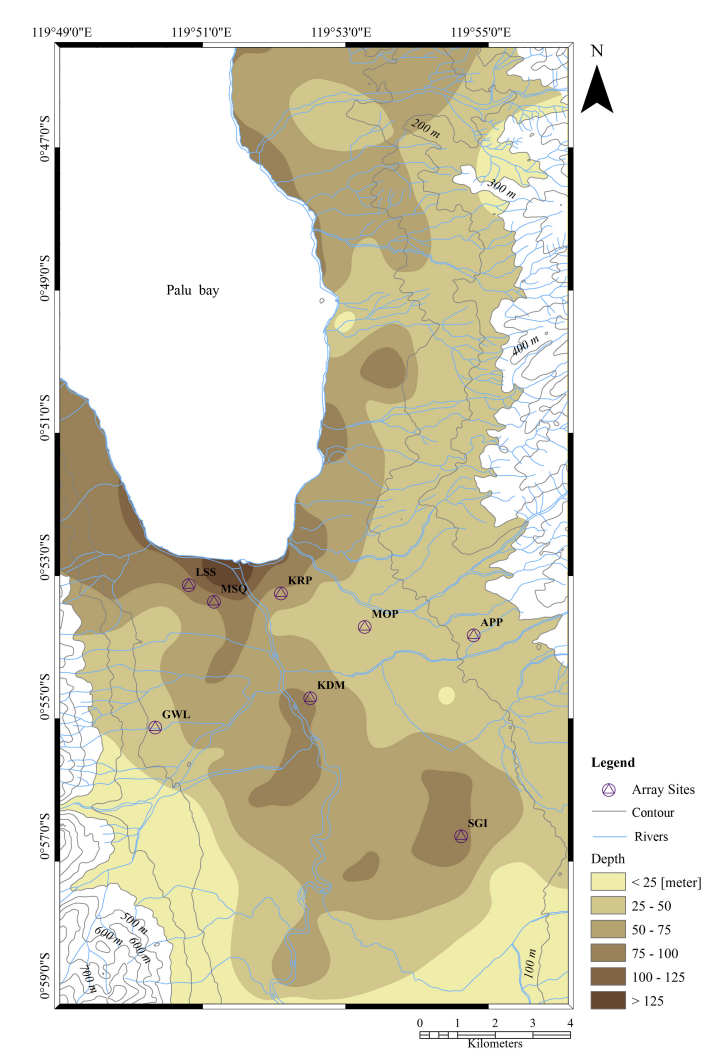

Figure 7: Depth of the engineering bed rock.

\section{Evaluation of subsurface soil profiles from boreholes}

The subsurface soil profiles and related geotechnical parameters have been evaluated in three sites for determination strong ground motion and ground response analyses. The detailed drilling program had been carried out for subsurface investigation in Palu basin. There are three boreholes throughout the basin especially in Palu area to evaluate the geotechnical properties of subsurface soil layers (Figure 3). The boreholes were generally drilled up to the bedrock. The subsurface soil profiles and soil types are determined according to United State Soil Classification (USCS) system, based on grained size analysis, Atterberg's Limits Test and drill logs. The evaluated subsurface profiles for each area in the basin are shown in the following figures $8 \mathrm{a}-\mathrm{b}$.

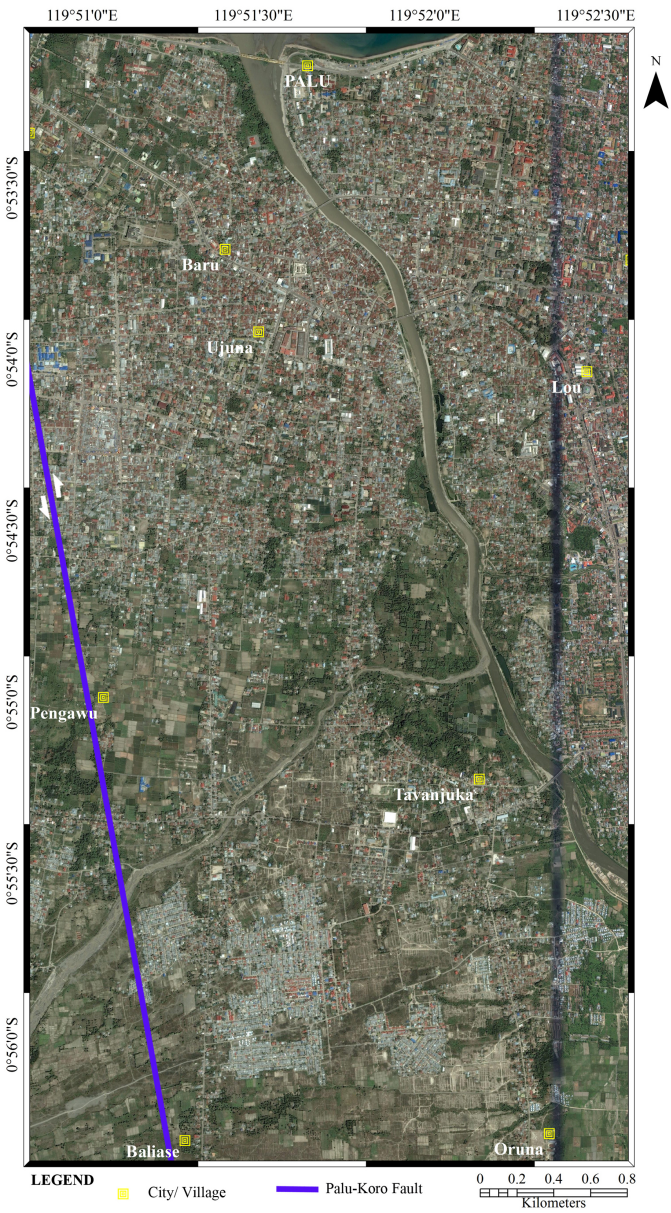

Figure 9: Location map of the Palu-Koro fault.

\section{Stochastic strong ground motion sim- ulations}

Strong ground motions of the Palu area were predicted based on the stochastic green's function method (Irikura et al., 2004). In this study, ground model is constructed by combining two layer model and average seismic bed rock model used in Japan, because there is no bed rock information in this area (Table 3). The fault model referred is an earthquake with moment magnitude of 6.3 on 23 January 2005 in Palu, Indonesia, of which epicenter was latitude $119.933^{\circ} \mathrm{E}$ and longitude $-1.198^{\circ} \mathrm{S}$. Figure 9 shows location map of the Palu-Koro fault.

\subsection{Peak ground acceleration and velocity}

Peak Ground Acceleration, PGA, is commonly used to describe ground motion because of their natural relationship to inertial force induced in 

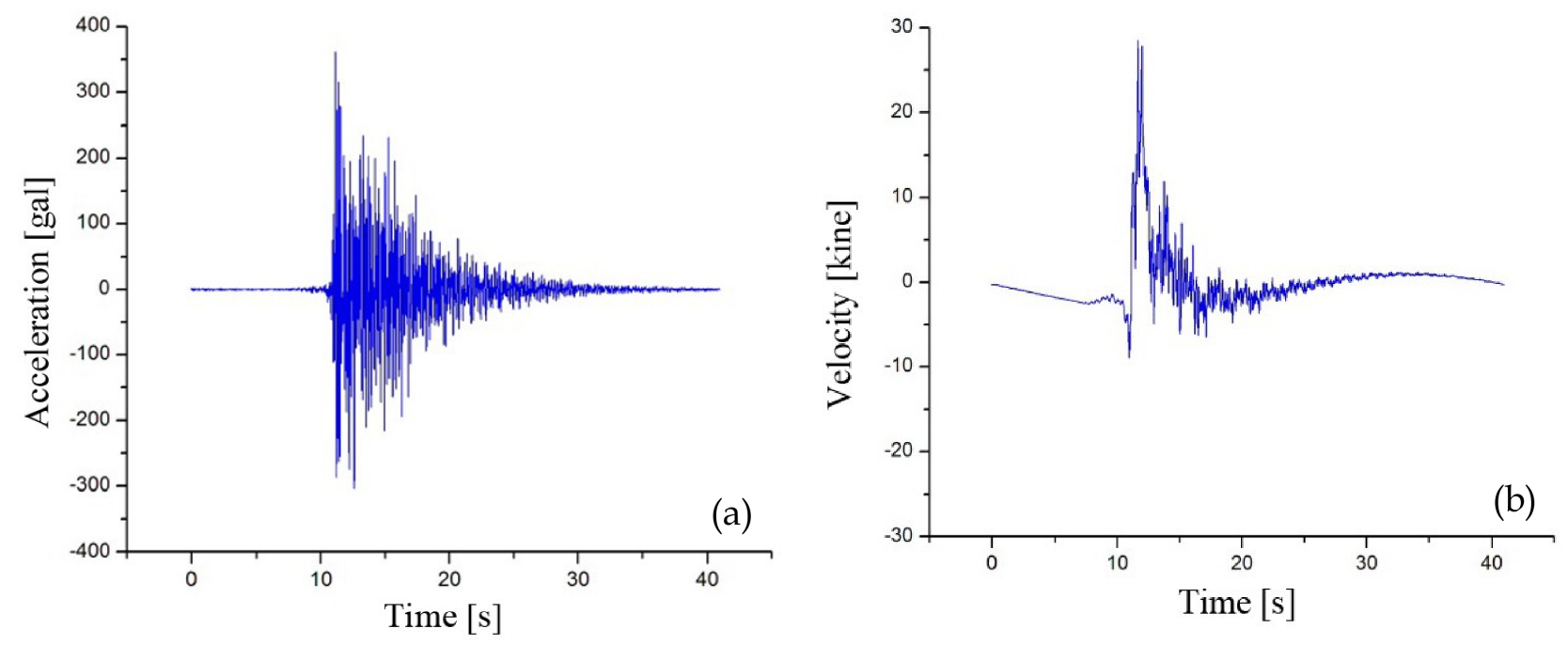

Figure 8: Soil Profiles of (a) Garuda and (b) Pengawu.

Table 3: Macroscopic source parameters

\begin{tabular}{|l|c|l|c|}
\hline Latitude & $119.933^{\circ} \mathrm{E}$ & Moment magnitude & $\mathrm{Mw}=6.3$ \\
\hline Longitude & $-1.198^{\circ} \mathrm{S}$ & Fault area $\left(\mathrm{km}^{2}\right)$ & 800 \\
\hline Top depth $(d, \mathrm{~km})$ & 0 & Shear wave velocity $(\mathrm{km} / \mathrm{s})$ & 3 \\
\hline Bottom depth $(\mathrm{km})$ & 20 & Mean density $\left(\rho, \mathrm{t} / \mathrm{m}^{3}\right)$ & 2.4 \\
\hline Length $(L, \mathrm{~km})$ & 40 & Modulus of rigidity $\left(\mu, \mathrm{N} / \mathrm{m}^{2}\right)$ & $2.1 \mathrm{E}+10$ \\
\hline Width $(W, \mathrm{~km})$ & 20 & Average slip $(\mathrm{m})$ & 0.21 \\
\hline Strike $\left(^{\circ}\right)$ & 342.1 & Rupture velocity $\left(V_{r}, \mathrm{~km} / \mathrm{s}\right)$ & 3 \\
\hline Slope $\left(^{\circ}\right)$ & 90 & High-frequency limit $(\mathrm{Hz})$ & 10 \\
\hline Slip angle $\left(^{\circ}\right)$ & 0 & & \\
\hline
\end{tabular}


certain types of structures are closely related to it. Based on acceleration histories of response analysis, PGA values are determined. The following Figure 10 (a) acceleration and (b) show and velocity time histories of APP sites. Distribution of the estimated peak ground accelerations and peak ground velocities are shown in Figure 11p and 11p. The component of the shaking is NS. There are high accelerations and velocities are as appears along the fault, especially near the epicenter. There occurred relatively large shaking at the mouth of Palu river because of the deeper thickness of the sediment. Peak acceleration becomes more than $0.40 \mathrm{~g}$ in some areas, which causes severe damage for buildings in high probability. To prevent severe damage, firstly we have to check the vulnerability of the building in Palu, and if necessary, we have to take a countermeasure for strengthening of the structures. This is the first trial to estimate the shaking and the damage under the condition of the occurrence of a future PaluKoro earthquake. We accumulate detailed information about not only the ground but also the inventory for disaster mitigation in Palu.

\subsection{Ground shear strain}

This research is to establish a simplified accurate method to evaluate the ground shear strain and vulnerability of the ground structures using microtremor. The vulnerability index is expected to be generalized as compared with actual earthquake damage. When shear deformation at ground surface at the time of earthquake is set to $\delta g$, the strain of surface ground $\gamma g$ is expressed as follows in approximation:

$$
\begin{aligned}
\gamma_{g} & =\delta_{g} / h \\
& =e \times a /\left(2 \pi F_{g}\right)^{2} \times 4 F_{g} / v_{s} \\
& =e \times A_{g} \times a /\left(\pi^{2} F_{g} v_{b}\right)^{2} \times v_{b} / v_{s} \\
& =\left(\frac{A_{g}^{2}}{F_{g}}\right) \times\left(\frac{e \times a}{\pi^{2} \times v_{b}}\right) \\
& \quad \gamma_{g}=K_{g} \times C \times a
\end{aligned}
$$

where,

$$
\begin{aligned}
K_{g} & =A_{g}^{2} / F_{g} \\
C & =e / 2 \cdot v_{b}
\end{aligned}
$$

$\gamma_{g}$ : shear strain (in powers of $\left.10^{-6}\right) ; A_{g}$ : amplification factor of the surface ground $(=$ $\left.v_{b} / v_{s}\right) ; F_{g}$ : natural frequency of the surface ground $(\mathrm{Hz})\left(=v_{s} / 4 h\right) ; a$ : maximum acceleration of the basement (Gal); $e$ : efficiency of the maximum acceleration; $v_{b}: S$-wave velocity of the basement $(\mathrm{m} / \mathrm{s}) ; v_{s}$ : S-wave velocity of surface ground $(\mathrm{m} / \mathrm{s}) ; h$ : thickness of surface ground.

Here, if it is assumed that it is $v_{b} \leq 1300 \mathrm{~m} / \mathrm{s}$ and $e=0.6$, it is come to $C=1.0$. Effective strain can be presumed as a value which multiplied by $K_{g}$ value and the maximum acceleration in case of an earthquake. $K_{g}$ value is an index peculiar to the measured ground, and it is possible to express the vulnerability of the ground. As shown in equation (8), $K_{g}$ value can be easily derived from natural frequency $F_{g}$ and amplification factor $A_{g}$ which were presumed in each measurement point. Figure 11k shows the ground shear strain map of Palu City.

\section{Conclusions}

The procedure employed and conclusions obtained in this study are as follows. Microtremor observations were carried out for constructing a subsurface ground model in Palu City. Singlepoint observations and array observations were conducted at 151 and 8 sites respectively, which covered almost the whole city area. The subsurface structure investigation had been performed by boring survey at three selected sites; Garuda, Pengawu and PDAM. Based on drill core data and SPT results, the simplified subsurface soil layers were evaluated. H/V spectra were calculated at all the single observation sites and a distribution of predominant periods was obtained. The dispersion curves of a Rayleigh wave were obtained from the data of array observations.By conducting an inversion analysis for the calculation of dispersion curves, the subsurface structure beneath the site can be estimated. It was constructed a four layered model in each array observation point. This research was reconstructed unified twolayered model by averaging the first three layers obtained from array observation. The shear wave velocity of the top layer is $V_{s} \leq 300 \mathrm{~m} / \mathrm{s}$. 

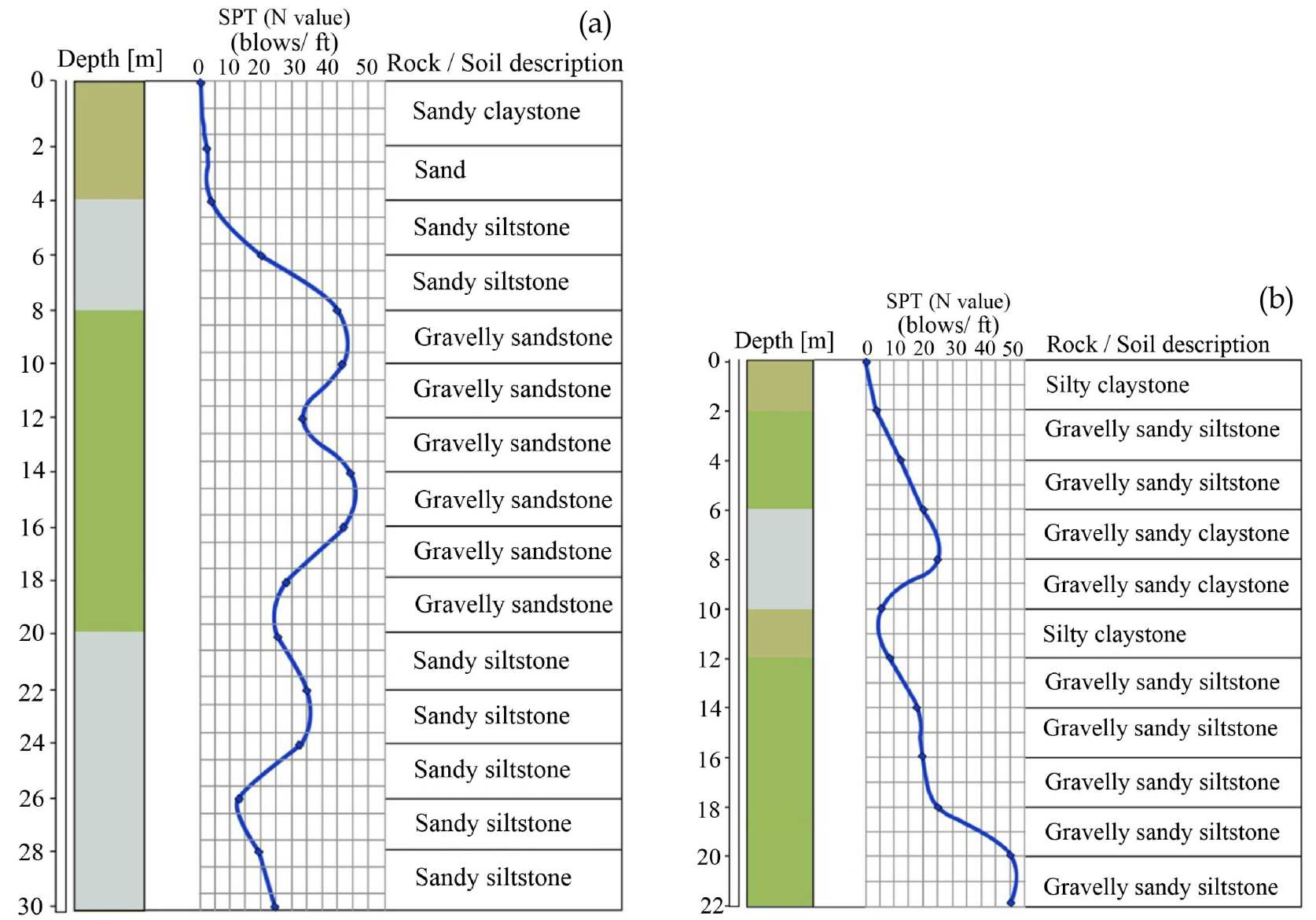

Figure 10: (a) Palu earthquake peak ground acceleration (North-South direction), and (b) peak ground velocity (Up-Down direction) record of APP site.
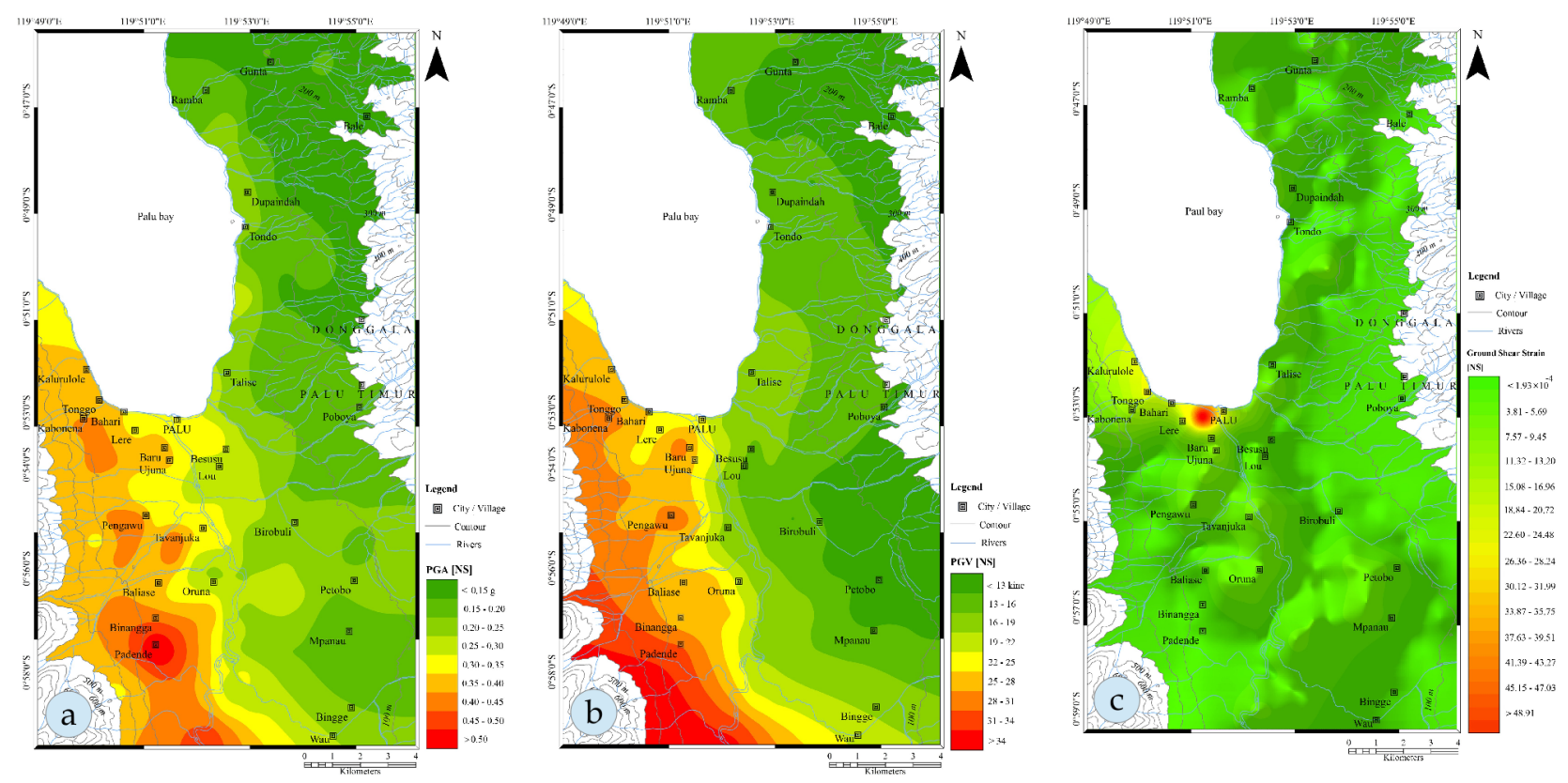

Figure 11: (a) Peak ground acceleration [NS] map on Palu area; (b) Peak ground velocity [NS] map on Palu area; (c) Map of Ground Shear Strain (NS) in Palu City. 
Three dimensional structure for shear wave velocities were (I) $V_{s} \leq 300 \mathrm{~m} / \mathrm{s}$, (II) $300 \mathrm{~m} / \mathrm{s} \leq$ $V_{s} \geq 1300 \mathrm{~m} / \mathrm{s}$ and (III) $V_{s} \geq 3000 \mathrm{~m} / \mathrm{s}$. By combining above two-layer model and the results of single point observation, the distribution of the first layer thickness of the sediment is obtained. The Kriging method can be used for the interpolation of subsurface information such as predominant period, shear wave velocity and depth of irregular boundary. Palu City had deposited on a thick alluvial layer in the coastal area (with a sedimentary layers between 75 and greater than $125 \mathrm{~m}$ ) that thins toward the mountains (with a sedimentary layers less than $25 \mathrm{~m}$ ). The subsurface geology also changes slowly from soft sedimentary layers in the coastal area to igneous intrusion and metamorphic rock in the mountains. The resulted PGA and PGV maps show that some severe damaged areas during January 23, 2005 earthquake is related to strong ground motion and some are related to high amplification of local sediments. Microtremor survey results showed that in hilly areas had low ground shear strain index, whereas in coastal alluvium was composed of material having a high ground shear strain indication.

\section{Acknowledgements}

This study was supported by the Grant-in-Aid of JICA/AUN SEED-Net. We gratefully acknowledge Dr. Noguchi, Dr. Ono in Tottori University, and Dr. Rusnardi Rahmat Putra in Kyoto University for their cooperation with the microtremor observations. We sincerely thank Dr Aiko Furukawa, Department of Urban Management, Graduate School of Engineering, Kyoto University for providing her invaluable support and encouragement during the research period in Kyoto and Tadulako Universities for their help in undertaking the observations in Palu, Indonesia.

\section{References}

Aki, K. (1957) Space and time spectra of stationary stochastic waves, with special refer- ent to microtremor, Bull. Earth. Res. Inst., vol. 35(3), pp. 415-456.

Ananda, S. R. (2013) Analisis dan Interpretasi Kelurusan Struktur Geologi Menggunakan Digital Elevation Model (DEM) ASTER Daerah Kecamatan Palu Timur dan Sigibiromaru, Kabupaten Donggala, Kota Palu, Gadjah Mada University, 2013.

Indra, I. I. A. (2013) Analisis dan Interpretasi Struktur Geologi Menggunakan Digital Elevation Model (DEM) ASTER Daerah Kecamatan Marawola, Dolo, dan Palu Barat, Kota Palu, Sulawesi Tengah, Gadjah Mada University, 2013.

Irikura, K., Miyake, H., Iwata, T., Kamae, K., Kawabe, H. and Dalguer, L. A (2004) Recipe for predicting strong ground motion from future large earthquake, Proceedings of the 13th World Conference on Earthquake Engineering, No. 1371.

Ismawan, G.F. (2013) Geologi dan Analisis Struktur Geologi Berdasarkan Digital Elevation Model (DEM) ASTER Daerah Palu Barat dan Marawola, Kota Palu, Poopinsi Sulawesi Tengah, Gadjah Mada University, 2013.

Juwanto, D. (2013) Studi Struktur Geologi Tepi Timur Lembah Palu Kecamatan Palu Timut, dan Tavaili, Kota Palu, Gadjah Mada University, 2013.

Keneddy, J. and Eberhart. R.C. (1995) Particle swarm optimization, Proc. of IEEE. International conference on Neural Networks, Vol.4, pp.1942-1948.

Kiyono, J. and Suzuki, M. (1996) Conditional Simulation of Stochastic Waves by Using Kalman Filter and Kriging Techniques, Proc. of the 11th World Conference on Earthquake Engineering, Acapulco, Mexico, No.1620.

Kiyono, J., Ono, Y., Sato, A., Noguchi, T. and Rusnardi, P.R. (2011) Estimation of subsurface structure based on Microtremor observations at Padang, Indonesia, ASEAN Engineering Journal, Vol.1, No.3, pp.66-81.

Noguchi, T., Horio, T., Kubo, M., Ono,Y., Kiyono, J., Ikeda, T. and Rusnardi, R.P. (2009) Estimation of Subsurface Structure in Padang, Indonesia by Using Microtremor Observation, Report on Earthquake Disaster Prevention Field, Tono Research Institute of 
Earthquake Science, Seq. No.26, pp.1-16, (in Japanese)

Pramumijoyo, S., Indarto, S., Widiwijayanti, C., and Sopaheluwakan, J. (1997) Seismic Parameters of the Palu-Koro Fault in Palu Depression Area, Central Sulawesi. Indonesia J. SE Asian Earth Sci.

Priadi, B. (1993) Geochimie du magmatisme de l'Ouestet du Nord de Sulawesi, Indonesia:Tracage des sources et implications geodynamique. Doctoral thesis, Universite Paul Sabatier, Toulouse, France.

Soekamto, R.A.B. (1995) Regional Geological
Map of Palu Sheet, Indonesia, Scale 1:250,000, Geological Research Center, Bandung.

Thein, P.S., Pramumijoyo, S., Brotopuspito, K.S., Wilopo, W., Kiyono, J and Setianto, A. (2013) Site response characteristics of H/V spectrum by microtremor single station observations at Palu City, Indonesia. Journal of Southeast Asian Applied Geology, Volume 5, Number 1, January-June 2013. ISBN 20865104. USGS, (2007), Historical World wide Earthquake (http:/ / earthquake.usgs.gov/). 